\title{
THE USE OF TEAM GAME TOURNAMENT (TGT) METHOD TO IMPROVE THE STUDENTS' READING COMPREHENSION
}

\author{
Safitri Nurchasanah \\ Universitas Islam Nahdlatul Ulama' Jepara, Indonesia \\ safitrinurchasanah3@gmail.com
}

\begin{abstract}
The objective of this research was to know the effectiveness of Teams Games Tournament (TGT) method to improve the students' reading comprehension at the eighth grades and also to help the English teachers more creative in teaching reading especially on reading comprehension at eighth grades. This research was true experimental design exactly PretestPosttest control group Design that involving two groups of classes. One group treated as the experimental class applied TGT and other group treated as controlled class applied conventional teaching strategy. The instrument of this research was reading comprehension test. In reading test, the result of the data indicated that there was a significant difference between students' post-test in both experimental and controlled class. In experimental class, the total mean score of the post-test was 94.75 was greater than the total mean score in controlled class was 77.25. From the t-test, the researcher found that the value the t-test in the post test was greater than the t-table $(8.616>2.000)$. Based on the findings and the discussion of the research, the researcher drew a conclusion that the use of Teams Games Tournament was effective to improve the students' reading comprehension at the eighth grades of SMPN 02 Jepara..
\end{abstract}

Keywords: Cooperative Learning; Team Game Tournamen; Reading Comprehension.

Indonesia has replaced the previous curriculum to the curriculum of 2013. There are four skills that students need to be good in English those are listening, speaking, reading and writing, however now is not only focusing on four skills. In this curriculum, students also need to understand and apply English in their daily need to get the knowledge. The students need to prepare the knowledge to continue the higher education or to face their future. English is one of the most languages to be learned and mastered around the world. As an international communication, English is the dominant language in some fields especially in education, technology, tourism, and science. People use English to open the door of the world because English becomes a foreign language of the subject studies in Indonesia.

In mastering English, students need the knowledge. The quality of their English depends on their knowledge to build, develop, or have communication. To get more knowledge, students need to read. Utomo (2014:59) states that reading is one of the receptive skills that should be learned by the students in Junior High School level. 
From reading, students can get a lot of input to acquire the language. Junior High School student is the basic English learners. In Junior High School there are some kinds of texts that have to be learned by the students.

$<$ | 48 It is very important to teach students read well and comprehend the content of the text. In the proper semester from $\mathrm{K}-13$, in the eighth grade of junior high school, students learn some of Genre texts and how to read and understand well about reading material. It means reading skill is a skill that need to concentrate and enjoyable during learning process. Adilla (2017:2) states that reading is one of the important components for students in English learning and reading also becomes the gates for the future. By reading, the students will understand all the things that they do not know before. Students successful in learning depends on how deep their comprehensive ability the meaning from the text. If they have low ability in reading, they will fail in the study, but they will success when they have a good ability in reading. Then, it means that reading skill must be learned by the students.

Gilakjani (2017:227) states that reading is an interactive process in which readers construct a meaningful representation of a text using effective reading strategies. Meanwhile, Utomo (2014:59) states that reading is a source and give the information contained in the text or about the language use. So, the teacher needs the responsibility to make students capable in comprehending a text especially to the basic level of the students learning English. In other words, reading is skill has a big role for the students to get information deeply from the text, so that it can increase the students' knowledge. Therefore, the English teacher should be more creative to increase the students' reading comprehension in teaching learning process. Unfortunately, not all teachers consider acting more creative in teaching reading or improving reading comprehension to the students. There are some problems that the researcher gets in teaching learning English to the students. The problems come from the students and the teacher. Some students feel difficult to comprehend and understand the English reading text, it happens because the students are lack vocabulary, so, they cannot get information from the reading texts. For example, after reading a text, the students cannot tell the content of the text and they could not answer the questions related to the text correctly. And some teachers only use a conventional method which monotonous and makes students passive and bored in teaching reading. In addition, it makes the students feel sleepy and get low motivation in learning reading text.

To solve the problem, the researcher needs to employ the suitable method so that the researcher employs Team Game Tournament (TGT) strategy. TGT is the learning strategy that designed by Robert Slavin which is suitable to review and students' mastering the material(Utomo, 2014:60). A lot of expert states that The Team Games Tournament is very simple to apply and it is also fun and challenging. Slavin $(2005: 163)$ state that TGT model is one type or model of cooperative learning that is easy to apply, involving the activities of all students seems to have no status difference, involving the role of students as peer tutors and contain elements of game and reinforcement.

Sitorus \& Surya, (2017:17) states that cooperative learning itself is a practice strategy where students learn in small groups that have different levels of qualification. While, Rusman, (2011:202) defines cooperative learning is learning process which the students learn and work in a small 
group as collaborative that consist of four or six members homogeneous. Prasetyo, (2012:2) argues Cooperative learning is derived from foreign words "cooperate" which means working together. Accordingly, Cooperative Learning is the way to get the common goal by learning together. Students have to work together to get success and responsible for the success of individual in their group. Cooperative learning is a teaching method where students of mixed levels of ability are arranged into groups and rewarded according to the group's success, rather than the success of an individual member (Anggraini, 2017:3).

Utomo (2014:60) defines that TGT method is an cooperative learning that focus on a group working which is able to build the students' confidence and ease them to comprehend the text by using this method the students can discuss certain topic with English language in their group or other group and also can give opinion or response from other student' opinion. Slavin (2005:163) states that TGT is a method that used in academic tournament and it used to develop the individual score system of the students by giving the quizzes. In other hand, Widhiastuti (2014:50) states that Team Game Tournament (TGT) method is a kind of cooperative learning that used as the alternative to solve the problem for the students.

Based on the previous researchers such as Anggraini, (2017) with the result of significant (2-tailed) is $0,002<0.05$ by using t-test, Utomo, (2014) with the result of last post-test were $64,70 \%$ and students got $>75$, Wardani, Syafri, \& Delfi (2015) with the result of first post-test 71.11 and incredibly improved to 80.06 in post-test II, Prasetyo, (2014) with the result of the first post-test 5.21 to 73.54 in post-test II, and Sitorus \& Surya (2017)showed the t_count $>t$ t_table or
$7.6081>1.69$ then the hypothesis $\mathrm{H} 0$ rejected and $\mathrm{Ha}$ accepted, those results are effective on students' reading comprehension. It can take the conclusion that TGT method can improve the students' comprehension and help students in reading comprehension.

From previous researches above, the researcher believes that Team Game Tournament (TGT) Method can be an effective way to improve the students' reading comprehension.

\section{METHOD}

Research methodology is a way to systematically solve the research problem. In this study, the writer used the experimental research. In this experiment, the writer intended to investigate the use of Team Game Tournament (TGT) as a method to improve the students' reading comprehension. Experimental research is a research method that used to find a specific treatment against the other in uncontrolled conditions (Mubarok, 2015:88). There are four kinds of experimental design such as pre-experimental, true-experimental, factorial design and quasi-experimental (Sugiyono, 2016:108-116). In this study, the writer used true-experimental design that is using the pretest-posttest control design. In this study, there were two classes, those were experimental group which was chosen randomly and control group which was also chosen randomly. The data of this study was collected by using test. Arikunto (2006:223) defines test is an instrument to measure ability and achievement. There were two tests that had been held in this study; pre-test and post-test describe as follows:

\section{a. Pre-test}

Pre-test was given at the first time before the writer implemented the treatment in both experimental and controlled class. Pre-test was given to know the student's 
comprehension in reading before implementation of the method.

\section{b. Treatments}

Treatments were given before the posttest. The students were treated by the writer

$<$ | $\mathbf{5 0}$ based on the group. The group was divided into two groups; experimental group and control group. The experimental group was treated by team game tournament method, and the control group was treated by conventional method. The treatment had been done in 3 meetings for both experimental and control group.

\section{c. Post-test}

Post-test was given at the last time as final test after the writer implemented the treatment. It was used to know the students' progress in learning reading comprehension after implementation of the method and whether or not team game tournament method was effective to teach students' reading comprehension.

\section{HYPOTHES TESTING}

This research aimed to answer the problem statement of reseach, the reseacher was find out the effectiveness of Team Game Tournament method to improve the students' reading comprehension (A True Experimental Study at the eighth grade of SMP N 2 Jepara in the academic year 2018/2019). To prove the hypothesis, the data obtained in experimental and control group were calcuated by using t-test formula manual and SPSS. Based on the discription of the data calculation, it shows that:

1. The $\mathrm{t}$-value was 8,616

2. The degree of freedom (df) was 62 , so the value of t-table was 2,000 in significance level of 0,05 .

It showed that the result of post-test both experimental and control group was t-value (8.616) was higher than t-table $(2,000)$. To conclude, the t-value $>\mathrm{t}$-table means that $\mathrm{H} 0$ (the Null hypothesis) was rejected and $\mathrm{Ha}$
(The Alternative hypothesis) was accepted. Moreover, the stating that "Team Games Tournament method is effective to improve the students' reading comprehension at the eight grade of SMP N 2 Jepara in the academic year 2018/2019".

\section{FINDINGS}

Team game tournament method was a teaching method which assigns students into groups that consists of four or five heterogeneous members in each group. Students in the experimental group were taught through team game tournament (TGT) and the control group was taught without team game tournament method. Both classes got pre-test and post-test.

The result of data pre-test and posttest happened in both classes, experimental group and control group. The experimental group which was taught through team game tournament method and the control group which was taught without team game tournament method. The experimental group which was taught by team game tournament method was higher to improve the students' reading comprehension than the control group which was taught without team game tournament method. The mean of pre-test in experimental group was $71.125\{71\}$, became $94.75\{95\}$ was mean score in post-test. Meanwhile, the mean score of the pre-test in control group was $65.75\{66\}$, and post-test was $77.34\{77\}$. It shows from the mean score of the post-test in the experimental group was higher than control group's posttest. In other side, the data analysis used ttest, the value to of pretest in experimental and control group was 1,948 with the degree of freedom 62 in the level significance $(\alpha)$ of $0,05, \mathrm{t}_{\text {table }}$ was 2,000 and the value to of posttest in experimental and control group was 8.616with the degree of freedom 62 in the level significance $(\alpha)$ of 0,05 , $\mathrm{t}_{\text {table }}$ was 
2,000.it means that $\mathrm{t}_{o}$ was higher than $\mathrm{t}_{\text {table }}$ in post-test of experimental and control groups only. So, the Null hypothesis (Ho) was rejected then alternative hypothesis was accepted that there was an effectiveness of team game tournament method to improve the students' reading comprehension at eighth grades of SMP N 02 Jepara in the academic year of 2018/2019.

Table.1.The T-test Result of Pre-test Score Experimental and Control Group.

Group Statistics

\begin{tabular}{|l|l|l|l|l|l|}
\hline & GROUP & N & Mean & $\begin{array}{l}\text { Std. } \\
\text { Deviation }\end{array}$ & $\begin{array}{l}\text { Std. Error } \\
\text { Mean }\end{array}$ \\
\hline PRETEST & GROUP 1 & 32 & 71,1250 & 10,64303 & 1,88144 \\
SCORE & GROUP 2 & 32 & 65,7500 & 11,75832 & 2,07860 \\
\hline
\end{tabular}

Independent Samples Test

\begin{tabular}{|c|c|c|c|c|c|c|c|c|c|c|}
\hline & \multicolumn{2}{|c|}{$\begin{array}{l}\text { Levene's } \\
\text { Test for } \\
\text { Equality of } \\
\text { Variances }\end{array}$} & \multicolumn{7}{|c|}{ t-test for Equality of Means } \\
\hline & & \multirow[t]{2}{*}{$\mathrm{F}$} & \multirow[t]{2}{*}{ Sig. } & \multirow[t]{2}{*}{$\mathrm{t}$} & \multirow[t]{2}{*}{ df } & \multirow{2}{*}{$\begin{array}{l}\text { Sig. } \\
(2- \\
\text { tailed } \\
)\end{array}$} & \multirow[t]{2}{*}{$\begin{array}{l}\text { Mean } \\
\text { Differe } \\
\text { nce }\end{array}$} & \multirow{2}{*}{$\begin{array}{l}\text { Std. } \\
\text { Error } \\
\text { Differ } \\
\text { ence }\end{array}$} & \multicolumn{2}{|c|}{$\begin{array}{l}95 \% \text { Confidence } \\
\text { Interval of the } \\
\text { Difference }\end{array}$} \\
\hline & & & & & & & & & Lower & Upper \\
\hline $\begin{array}{l}\text { PRET } \\
\text { EST } \\
\text { SCOR } \\
\text { E }\end{array}$ & $\begin{array}{l}\text { Equal } \\
\text { variances } \\
\text { assumed } \\
\text { Equal } \\
\text { variances } \\
\text { not } \\
\text { assumed }\end{array}$ & 1,691 & ,198 & 1,917 & $\begin{array}{l}61,39 \\
4\end{array}$ & ,060 & $\begin{array}{l}5,3750 \\
0 \\
\\
5,3750 \\
0\end{array}$ & $\mid \begin{array}{l}2,803 \\
64 \\
\\
2,803 \\
64\end{array}$ & $\begin{array}{l}- \\
, 22939 \\
- \\
, 23049\end{array}$ & $\begin{array}{l}10,9793 \\
9 \\
10,9804 \\
9\end{array}$ \\
\hline
\end{tabular}

In the independent sample test table described about the value of this research. The result of t-value in this research was 1.917.It showed that $t$-value $(1,917)$ of pre $<$ t-table $(2,000)$. So, there was no 

Table 2.The T-test Result of Post-Test Score Experimental and Control Group.

Group Statistics

\begin{tabular}{|c|c|c|c|c|c|}
\hline & $\begin{array}{l}\text { GROU } \\
P\end{array}$ & $\mathrm{~N}$ & Mean & Std. Deviation & Std. Error Mean \\
\hline $\begin{array}{l}\text { POSTTE } \\
\text { ST } \\
\text { SCORE }\end{array}$ & $\begin{array}{l}\text { GROU } \\
\text { P } 1 \\
\text { GROU } \\
\text { P } 2\end{array}$ & 32 & $\begin{array}{l}94,7500 \\
77,2500\end{array}$ & $\begin{array}{l}5,78652 \\
9,92553\end{array}$ & $\begin{array}{l}1,02292 \\
1,75460\end{array}$ \\
\hline
\end{tabular}

The independent sample test table also described about the value of this research. The result of t-value in this research was 8,616. Furthermore, the t-value was compared to the t-table to know whether through Team Game Tournament the students can improve their reading comprehension or not. The t-table was taken from the requirement of t-table to analyse the data. The t-table of 0,05 as the significant level was 2,000 with 62 the degree of freedom (df). Then, it can be stated that $\mathrm{t}$ value $(8,161)$ of post-test $>$ t-table $(2,000)$.It can be concluded that Team Game Tournament (TGT) method can improve the students' reading comprehension at the eighth grades of SMP $\mathrm{N} 02$ Jepara in the academic year of 2018/2019.

\section{DISCUSSION}

The aim of this research was to know the effectiveness of TGT method to improve the students' reading comprehension at the eighth grades. The research was conducted in two classes. They were experimental class and control class. The experimental was implemented by TGT method and the control class was implemented without TGT method.

In choosing the sample, the researcher should be careful because in cooperative learning, some factors can affect it. The time allocation was also affected the result of cooperative learning implementation. The classification of choosing the samples in this research was based on the test score data which was gained from the teacher. It was based on the daily test score.

Before conducting the treatment, the pre-test was done. It was conducted in order to know reading comprehension of the students before the treatment given. Then, after asking the students to do the pre-test, the researcher was ready to give the treatment. The treatment was implementing TGT for experimental class and conventional teaching for control class. There were three times treatments for each class. The researcher tried to plan and organize the research well because it can influence the result of the implementation.

In implementing TGT, firstly the researcher told to the students that they would be taught by cooperative learning 
which called TGT method then the researcher gave the explanation dealt with the material. Here was the recount text. The explanation was about the purpose of recount text, language features, and generic $<$ | 52 structures. Moreover, the researcher gave the example of recount text. Secondly, the students were divided into six groups. It consisted of five students in each groups. In assigning the students to teams, the researcher used some criteria. Due to one of consideration of formatting the groups in cooperative learning is the teams should be heterogeneous. It was based on the score, and the gender. In a team should consist of high performing students and average performing student. Thirdly, the students were given the material to be understood. The material was recount text. Fourthly, the researcher divided the quizzes in every tournament table and the researcher arranged the table tournament which consisted of six students from different groups with different ability which was classified by the scores. Fifthly, the students in tournament tables did game tournament. The ways were each student in turn picked a card, read the question out loud and tried to answer the question. If she or he could answer, she or he could keep the card. If she or he could not answer, the challenger could answer. Then if the challenger could not answer, he or she should return a previously won card (if any) to the deck. For the next round, the turn moved one position left, the first challenger became the reader. The student was next to the reader kept the key answer to match the reader answer with the correct answer. All the students in the each tournament tables played the same game at the same time. The teacher was only as facilitator who moved from group to group to make sure that everyone understood the game procedures. After all the students in all tournament tables had already finished the game, the students were asked to count the cards that they gained. After that, each tournament table had game score sheet. It was used to write the score of each student who came from different teams. Then, each student went back to their teams. They reported their score to the team mates and wrote the scores in the Team Summary Sheet.

Furthermore, in control class the researcher only used the conventional method. The researcher explained the material about recount text. After explaining the material the researcher asked the students to do the exercise on English book and collected the result to the researcher.

Based on the result of conducting the treatment the students in experimental group looked enjoy and more attractive in learning activity, because they learnt with playing games. In teaching learning, the teacher assigned the students to four or five team's members. Each team should be heterogeneous. Students could work with their friends to solve the problems and to achieve the goals. Slavin (2005:163) state that TGT model is one type or model of cooperative learning that is easy to apply, involving the activities of all students seems to have no status difference, involving the role of students as peer tutors and contain elements of game and reinforcement.

\section{CONCLUSION}

Based on the result and discussion above, it showed that the students' reading comprehension at the eighth grade of SMP N 2 Jepara can be improved by using Team Game Tournament Method. It could be seen by students' mean score was increased. In experimental group, the mean score of the pre-test was 71.125 and the mean score of the post-test was 94.75. After applied TGT method in learning process, the students' 
reading comprehension was improved. In control group, the mean score of the pre-test was 65.75 and the post-test was 77.25. Based on the data analysis of t-test, the mean score of the post-test in experimental and control group showed that $\mathrm{t}$-value was 8.616 and $\mathrm{t}$ table of 0,05 as the significance level was 2,000 with 62 the degree of freedom (df). It can be described that the t-value $(8,616)>t-$ table $(2,000)$. In addition, the result of t-test also showed that H0 (the Null Hypothesis) was rejected and $\mathrm{Ha}$ (the Alternative hypothesis) was accepted. It can be concluded that there were the effect of Team Game Tournament (TGT) method in improving the students' reading comprehension.

\section{REFERENCES}

Adilla, A. N. (2017a). The Effectiveness Of Teams Games Tournament (Tgt) Technique In Teaching Reading At The Tenth Grade Of Sma $N 1$ Wonosari In Academic Year 2015/2016. Uin Surakarta.

Anggraini, M. (2017). The Effect of Team Games Tournament (TGT) Method on Students' Reading Comprehension of Recount Text, (2014), 1-10.

Arikunto. (2006). Prosedur Penelitian Suatu Pendekatan Praktek. Jakarta: PT. Rineka Cipta.

Gilakjani, A. P. (2017). How Can Students Improve Their Reading Comprehension Skill?, (June 2016). http://doi.org/10.5296/jse.v6i2.9201

Prasetyo, S. (2012). The Usage Of Teams Games Tournamet Method In Teaching Vocabulary In Elementary School. E-Journal.

Slavin, R. E. (2005). Cooperative Learning: Teori, Riset dan Praktik. Bandung: Nusa Media. Mubarok, H. (2015). Research in Language Education:An Intriduction for beginners. Jogjakarta: Lingkar Media.

Rusman. (2011). Model-Model Pembelajaran (Pengembangan Profesionalisme Guru). Jakarta: PT. Raja Grafindo Persada.

Sitorus, E. N., \& Surya, E. (2017). The Influence of Teams Games Tournament Cooperative Learning Model on Students ' Creativity Learning Math .... The Influence of Teams Games Tournament Cooperative Learning Model on Students ' Creativity Learning Mathematics, (February).

Sugiyono. (2016). Metode Penelitian Pendidikan Pendekatan Kuantitatif, Kualitatif, dan $R \& D$. Bandung: Alfabeta.

Utomo, M. S. (2014). The Implementation Of Team Game Tournament (Tgt) Strategy For Teaching Reading Narrative Text Muhyidin Setyo Utomo. Journal, 59-65.

Widhiastuti, R. \& F. (2014). Teams Games Tournament (Tgt) Sebagai Metode Untuk Meningkatkan Keaktifan Dan Kemampuan Belajar, Vol. Ix, N, 48 
$\longrightarrow$

$\ll \mid 54$ 